\title{
O suplício de Tântalo: moeda, economia e sociedade brasileira entre 1845 e 1866
}

The Torture of Tantalus: Currency, Economy, and Brazilian Society Between 1845 and 1866

Hernán Enrique Lara Sáez ${ }^{*}$

\section{Resumo}

Tal como na lenda mitológica sobre o suplício de Tântalo, é possível perceber nos debates parlamentares brasileiros, entre 1845 e 1866 , a ansiedade e a frustração geradas pela formulação de planos econômicos e por projetos de estabilidade. As discussões sobre os projetos reformistas são importantes registros de como a elite política brasileira tratou de fazer frente a um cenário internacional instável em razão da quebra da Overend \& Gurnay e do prenúncio da guerra Austro-Prussiana, somados à crise brasileira de 1864 e à Guerra do Paraguai. Os parlamentares debateram as medidas necessárias para reforçar a economia nacional impedindo a queda no valor da moeda e considerando as nossas peculiaridades. Buscavam, na medida do possível, manter a economia brasileira atuante e o sistema bancário funcional, a despeito das flutuações de uma economia mercantil escravista.

Palavras-chave: política econômica; debates parlamentares; Crise de 1864; Segundo Reinado.

\section{Abstract}

As in the mythological legend about the torture of Tantalus, it is possible to perceive in the Brazilian parliamentary debates, between 1845 and 1866, the anxiety and frustration produced by the formulation of economic plans and stability projects. Discussions on reformist projects are important records of how the Brazilian political elite tried to cope with an unstable international scenario due to the breakdown of Overend \& Gurnay and the foreshadowing of the Austro-Prussian War combined with the Brazilian crisis of 1864 and the War of Paraguay. Parliamentarians discussed necessary measures to strengthen the national economy by preventing the fall in the value of the currency while taking into account our peculiarities. They sought, as far as possible, to keep Brazilian economy active and the banking system functional despite the fluctuations of a slave trading economy.

Keywords: economic policy; parliamentary debates; Crisis of 1864; Second Empire.

\footnotetext{
* Fundação Dom Aguirre, Sorocaba, SP, Brasil. hernanlsaez@gmail.com <http://orcid.org/0000-00021204-6714>
} 


\section{O SUPLÍ́CIO DE TÂNTALO: ANSIEDADE E FRUSTRAÇÃO NAS POLÍTICAS ECONÔMICAS}

Conta a lenda que Tântalo foi sentenciado a ficar enclausurado por desobediência aos deuses e amaldiçoado - mesmo sedento, não conseguia tomar água porque o líquido retrocedia à medida que ele se aproximava; tampouco podia comer frutas, porque uma forte ventania afastava os galhos quando tentava colher alguma. Assim, o suplício imposto consistia em viver a ansiedade de tê-los próximos e a eterna frustração de perdê-los quando já estavam quase em suas mãos (Homero, 2006, p. 139).

Essa fábula simboliza alguns dilemas pelos quais passou a elite política imperial brasileira e que estão presentes nos debates parlamentares. Nesse sentido, podem ser considerados como suplícios de Tântalo: o anseio pela recuperação do valor da moeda brasileira, em queda desde 1845; a expectativa pelo afluxo de ouro, uma vez que o metal escoava na balança comercial deficitária; o perene interesse das elites em organizar um sistema bancário, com parte dos políticos defendendo que esse sistema fosse coordenado desde o Rio de Janeiro, facilitando, assim, o controle da moeda; a reforma do Banco do Brasil, de 1853, que dotava a instituição do privilégio de emissão de notas com curso forçado, atendendo prioritariamente o comércio.

Assim, este artigo acompanha o desenrolar dos debates sobre projetos de reforma do Banco do Brasil, enfocando os aspectos políticos, os argumentos e os consensos formados para sua aprovação.

A dúvida que pairava nos debates sobre a política econômica do período poderia ser sintetizada em: como trazer metais preciosos para uma economia que parecia não se metalizar? Provavelmente, quem melhor expressou a frustração pelas inalcançáveis benesses prometidas na adoção de medidas para conseguir ouro, no começo da década de 1850, foi Antônio Francisco de Paula Souza, representante da província de São Paulo e destacado político liberal que chegou a assumir a pasta do Ministério da Agricultura no gabinete encabeçado pelo marquês de Olinda (Abreu, 2004, p. 377). Dizia ele: "Sr. Presidente, eis em que deu a escola metálica!! Vinte anos perdidos! Éramos ameaçados de ser afogados em ouro, e nós estamos mais próximos de ser abafados em papel-moeda! Prometia-se-nos uma idade de ouro, e nós vamos entrar na idade do papelório! Que contraste, que singular contradição!” (ACD, 1 set. 1866, p. 178). 
BREVE Histórico dos PROJETOS DE “MELHORIA DA MOEDA”

O intempestivo aparte de Paula Souza resultava da frustração dos anos de estudos e debates acerca da depreciação da moeda no Brasil. Já em 1845, o então ministro da Fazenda, Manoel do Alves Branco, famoso liberal nascido na Bahia, encaminhava um audacioso projeto que, nas discussões no Parlamento foi chamado de projeto de melhoria da moeda. Entre outros itens o ministro propunha que parte crescente dos pagamentos feitos ao governo deveriam ser realizados em moeda metálica e, assim, em 25 anos os pagamentos recebidos seriam metade em papel e metade em metais. Além disso, apresentava a necessidade da fundação de um novo banco nacional, tendo em vista a falência do primeiro, em 1829, de forma que ele pudesse gerenciar o meio circulante, dando-lhe estabilidade, e instrumentalizasse o governo em relação aos seus projetos econômicos.

Foi com essa preocupação que o novo Banco do Brasil surgiu, em 1853, da fusão do Banco do Brasil, de Mauá, e do Banco Comercial do Rio de Janeiro, sob os auspícios do então ministro da Fazenda, o visconde de Itaboraí, nascido no Rio de Janeiro e pertencente à trindade Saquarema. Nos debates sobre o surgimento desse estabelecimento, duas posições se cristalizaram com a defesa de certos pressupostos econômicos: a de Itaboraí, defendendo a necessidade de as instituições bancárias manterem um fundo de reserva metálico com proporção rígida de emissão em relação a esse fundo, e a criação de caixas filiais onde fosse necessário.

Na posição contrária estava Bernardo de Souza Franco, liberal representante do Pará, que defendia a possibilidade de as instituições bancárias terem fundos não necessariamente metálicos, com maior flexibilidade nas emissões e a implantação da pluralidade bancária na qual os capitalistas conseguissem reunir condições mínimas para criar um banco.

Por assumirem essas posições nos debates os políticos ficaram identificados com as escolas econômicas inglesas que professavam e passaram a ser conhecidos na historiografia como "metalistas" e "papelistas" (Andrade, 1987).

Apesar de, em linhas gerais, a política até 1860 ter seguido um rumo mais restritivo adotado pelo visconde de Itaboraí, seu rival, Bernardo de Souza Franco, assumiu a pasta do Ministério da Fazenda entre 1857 e 1858, e nesse curto período implantou a pluralidade bancária e minou o monopólio de emissão concedido formalmente ao Banco do Brasil desde 1853. Portanto, entre 1853 e 1857, legalmente, apenas o Banco do Brasil poderia emitir bilhetes com 
curso forçado e, em contrapartida, resgatar as notas do Tesouro em circulação desde a falência do primeiro Banco do Brasil.

Conforme Gambi (2010, p. 178), baseado nos trabalhos de Amaro Cavalcanti e Vitor Viana, firmas, indivíduos particulares e bancos emitiam vales ou títulos semelhantes às notas bancárias, o que levou a reclamações da diretoria do banco, mas estas eram emissões ilegais e que geraram uma série de problemas e novos debates entre 1860 e 1866 (Sáez, 2015).

As gestões posteriores à de Souza Franco no Ministério da Fazenda, de Francisco de Sales Torres Homem, o visconde de Inhomirim, e Ângelo Moniz da Silva Ferraz, o barão de Uruguaiana, ambos conservadores, preocuparam-se em retomar o caráter restritivo da emissão. Principalmente Silva Ferraz implantou uma legislação que ficou conhecida com Lei dos Entraves, em 1860, que impunha aos bancos a troca das notas em ouro, à vontade do portador, o que, na prática, renovou o monopólio de emissão do Banco do Brasil tendo em vista que era a única instituição capaz de fazê-lo. É no complexo cenário da primeira metade da década de 1860 que figuraram, internamente, os efeitos da lei dos Entraves, a quebra do Souto e o começo da Guerra do Paraguai, e, externamente, a falência de uma grande casa bancária, a Overend \& Gurney, na Inglaterra, e a agitação de uma grande guerra entre duas potências no movimento da guerra Austro-Prussiana. Com esse cenário é que a nova reforma do Banco do Brasil, de 1866, representou um abandono do ideal metalista defendido por Itaboraí como essencial para a estabilidade econômica do Brasil.

\section{4: GUERRA E CRISE}

Este artigo busca colaborar no aprofundamento da compreensão da proposição, dos embates e das decisões acerca das medidas reformistas, tratando de enfocar mais as questões relativas às articulações políticas do que ao funcionamento dos modelos econômicos. É importante perceber a complexa arquitetura política da segunda metade do século XIX como fruto de uma construção que articulava localidades, regiões e, na escala mais abrangente, a nação (Andrade, 2015). Assim, a compreensão do funcionamento da monarquia constitucional representativa, no Brasil, conferiu ao Poder Legislativo uma centralidade ímpar, de modo que com todos os percalços, entre 1850 e 1866, o processo de tramitação das medidas, mesmo as financeiras, não foi alterado em razão de sua importância.

Com essa situação em mente, identifica-se que o período posterior à crise de 1864, conhecida no Rio de Janeiro como A Crise do Souto, trouxe a 
necessidade de reorganização das finanças cariocas com uma consequente reformulação das posições tradicionais capitaneadas pelo visconde de Itaboraí, metalista, e por Bernardo de Souza Franco, "papelista”, dadas as conjunturas enfrentadas pelo Brasil.

A casa bancária de Antônio José Alves Souto fechou as portas no dia 10 de setembro de 1864, mas somente nos dias subsequentes o pânico tomou conta do sistema bancário do Rio de Janeiro. De acordo com as Atas do Conselho de Estado Pleno (ACEP, $3^{\circ}$ CE, 1857-1864, p. 5), com medo das perdas, muitos poupadores com grandes depósitos e até centenas de pequenos correntistas apressaram-se em tentar retirar suas economias das instituições bancárias, criando um efeito em cadeia (Oliveira, 2016). Tal qual aconteceria na crise do banco Overend \& Gurney outras casas bancárias e até mesmo grandes bancos sofreram a pressão dos correntistas no Rio de Janeiro (Andrade, 1987, p. 197).

No caso carioca, um grande número de casas bancárias não conseguiu dar conta de tantos saques e acabou suspendendo os pagamentos, o que apenas reforçou o clima de medo e frustração dos correntistas. Apesar dos esforços de alguns deles para cobrir a retirada maciça de dinheiro no estopim da crise, depois de alguns dias seus fundos se esgotaram. Como estavam inseridos em transações triangulares de empréstimos, financiamentos, créditos etc., o fechamento desses estabelecimentos acabou disseminando a crise por toda a economia fluminense (ACEP, $3^{\circ} \mathrm{CE}, 1857-1864$, p. 5). Tanto nessa situação, como em outras de quebra de casas bancárias, surgiram reclamações sobre os comportamentos personalistas, clientelistas e irresponsáveis no campo econômico; no entanto, conforme apareceu no decreto emergencial promulgado em 1864 para tratar das falências, os Bancos e as casas bancárias eram tidas como importantes em suas transações com o povo, nas relações estabelecidas com o comércio e a agricultura e pelo importante papel que desempenhavam na oferta de crédito (Oliveira, 2016, p. 11).

Voltando a atenção para o campo político, especialmente o discursivo, a década de 1860 trouxe mudanças até mesmo na antiga exigência do apartidarismo presente nos discursos parlamentares entre 1850 e 1864. Essa exigência foi tida na maior parte do período como um aspecto que ressaltava a maturidade com que os políticos deveriam lidar com questões de fundamental importância como, por exemplo, o sistema bancário, o sistema monetário, o crédito agrícola e os planos econômicos. Assim, o fato de não haver menções constantes a partidos políticos, especialmente antes de 1860, não implica dizer que os partidos políticos eram mero artifício das elites. Na realidade, por todo o levantamento das discussões econômicas é possível entrever uma transformação 
histórica do conceito de "partido político", bem como das práticas partidárias, mais acentuadamente entre 1860 e 1864 .

Assim, a divisão de partidos políticos tinha sentido, e em algumas questões eles tinham propostas diferentes sobre os temas em discussão, mas a declaração explícita dessas posições foi duramente combatida pelos deputados até 1860, nas questões entendidas como de interesse nacional.

A questão alterou-se, especialmente, com a Guerra do Paraguai, quando o problema principal passou a ser a manutenção de uma política restritiva e, simultaneamente, o enfrentamento dos custos de um conflito armado. Naquele momento, essa contradição foi tratada com cuidado redobrado, afinal, como lembrou em plenário João José de Oliveira Junqueira Júnior, conservador e representante da Bahia, o dinheiro era o nervo da guerra.

Mesmo nesse quesito tão melindroso, o tema precisava passar pelo crivo dos parlamentares nas votações, sendo elementos indispensáveis a apreciação das medidas pelos discordantes, a discussão madura e a negociação política buscando apoio aos projetos apresentados.

A análise das questões do período é complexa, sobretudo, porque é difícil perceber a diferença entre as posições partidárias e as posições pessoais na forma como se contemplavam as questões públicas, pelo menos até 1864. Além disso, se os alinhamentos políticos tornaram-se mais explícitos, muitas vezes a pedido dos próprios parlamentares, essas declarações facilitavam as cobranças da opinião pública e dificultavam a desvinculação de nomes e apoios a determinados projetos, o que mudava o jogo político.

Ao que parece, esse período foi difícil para os porta-vozes políticos porque exigiu deles uma maleabilidade recorrente e o cuidado constante em não colidir com o esforço de guerra. A situação desafiou oradores, por vezes comprometidos por seu histórico nas votações, mas, ao mesmo tempo, essa alteração se apresentou como oportunidade para uma nova gama de representantes públicos envolvidos nas discussões sobre economia e política econômica. Estes últimos parecem ter ficado mais à vontade para escolher posições ou realizar críticas, simplesmente porque não tinham empenhado seu voto ou assumido a defesa pública de um projeto no final de 1850. Talvez essa conjuntura tenha beneficiado a Liga Progressista e inflado suas fileiras, incorporando reivindicações de descontentes com as políticas públicas e trazendo para a arena política novos interesses a serem contemplados nas discussões da década de 1860 .

A negociação política foi transformada pela composição híbrida da Câmara dos Deputados e resultava, em parte, do surgimento da Liga Progressista no cenário político, o que afetou todos os gabinetes do período. 
Segundo Wilma Peres Costa (1996), a Liga era uma migração de conservadores moderados em direção aos liberais, a coalizão dos altos escalões dos dois partidos (Costa, 1996, p. 222), uma visão muito parecida com a de Eide Sandra Abreu (2004), para quem a cisão entre os conservadores resultou da Lei dos Entraves (Abreu, 2004, p. 1).

Foi com essa nova situação que o governo imperial teve de lidar, buscando negociar com os parlamentares uma reorganização financeira que atendesse ao mesmo tempo aos anseios de valorização da moeda e à oferta de crédito. Em certa medida, as críticas anunciadas no Parlamento demonstravam o descontentamento com a administração do Banco do Brasil, a relação entre fundo de reserva e suas emissões, mas, talvez, o fator mais inesperado para os políticos em razão de seu peso crescente foi como manter a política restritiva com o financiamento da Guerra do Paraguai.

Era difícil manter uma sólida base de apoio político para aprovação de medidas concernentes à frente de batalha e manter a economia nos trilhos, impedindo o excesso de emissão de notas. Entretanto, a política econômica mantida não ficou imune a críticas, algumas delas raivosas, pelo modo como se conduziam as finanças na guerra e pelas posições políticas que os articuladores parlamentares assumiram nesse momento.

Novamente, a questão econômico-financeira colocava-se como fundamental, pois permitia aproximações e distanciamentos entre parlamentares, mas também desafiava a coerência política em um ambiente fugidio em relação à tradicional divisão partidária imperial entre conservadores e liberais. Essa conjuntura representava para a opinião pública um teste de patriotismo dos políticos. Assim, se por um lado acreditava-se que ela podia facilitar a ação do governo por supostamente minorar as críticas, de outro, munia os opositores com o argumento de que, nessa situação belicosa, era preciso uma análise dura e virtuosa dos projetos.

\section{Os PROJETOS DE 1866}

Em abril de 1866, o então ministro da Fazenda João da Silva Carrão, nascido em Curitiba, advogado liberal, fez uma apreciação do estado em que se encontrava o Banco do Brasil. Segundo ele, a instituição sofria os efeitos das providências tomadas na Crise do Souto, em 1864, pelas quais o banco nacional ficava autorizado a aumentar a emissão até o triplo do fundo disponível para salvar a praça comercial, além da determinação que transformava seus bilhetes em moeda legal nas áreas de existência do banco e das caixas filiais. 
Como a adoção das medidas emergenciais gerava efeitos colaterais nocivos à economia, Silva Carrão buscava o apoio do Poder Legislativo para readequar emissões (Coleção das Leis do Império, 1853, p. 15). Entre as medidas trazidas por seu projeto constavam: pagar ao banco 11 mil contos referentes ao resgate de notas do Tesouro; conceder apólices da dívida pública em troca do desconto que o Banco do Brasil faria das letras do Tesouro; conceder uma nova emissão com bilhetes confeccionados pelo Tesouro Nacional, obrigando o banco a manter o resgate das notas do Tesouro em circulação; e, por fim, a limitação de emissão. Terminada a apreciação do projeto, ele foi enviado à Comissão da Fazenda da Câmara dos Deputados para que se emitisse um parecer sobre ele (ACD, 7 abr. 1866, p. 74).

Antes mesmo que saísse o parecer sobre a proposta de Carrão, outro ministro, Antônio Francisco de Paula Souza, da Agricultura, apresentou projeto urgente para socorrer a praça comercial do Rio de Janeiro. Esse ministro justificou a súbita medida afirmando que:

a circunstâncias peculiaríssimas do Banco do Brasil, e principalmente às notícias ultimamente trazidas pelo paquete inglês, que embora não produzissem já resultados imediatos, é possível, e mesmo provável, que mais tarde o tenham de exercer desagradável repercussão em nosso país. [...] Não pode, portanto, satisfazer às exigências do momento, que diariamente tornam mais urgente a necessidade de armar o governo dos meios e recursos que possam prevenir os resultados provenientes da repercussão das notícias da Europa. (ACD, 11 jun. 1866)

Paula Souza referia-se à quadra de crise generalizada que assolava a Europa, conjugando a falência de uma grande casa bancária ocorrida em maio de 1866, a Overend \& Gurney, e a agitação pela ameaça da eclosão da guerra Austro-Prussiana. Embora essa manifestação pareça exagerada, outras fontes reforçam a ideia de que o banco de fato tinha um potencial econômico impressionante. Após a notícia da suspensão de pagamentos pela quebra dessa casa bancária, muitos correntistas seguiram para o escritório do Banco da Inglaterra, pressionando os responsáveis para que tomassem alguma providência. Tinham em vista que o banco de descontos Overend \& Gurney oferecia empréstimos para outros bancos comerciais e, aparentemente, para muitos particulares. Isso criou uma cadeia de empréstimos que colocava em risco boa parte do sistema bancário londrino - segundo alguns prognósticos, no mínimo a metade do sistema (Irwin, 2014, p. 17). 
De acordo com o novo projeto proposto por Paula Souza, o Banco do Brasil ficou autorizado a realizar uma emissão extraordinária de 8 mil contos acima do triplo do fundo disponível e a quantia necessária para descontar qualquer bilhete do Tesouro Nacional que fosse apresentado ao banco. Os lucros advindos da operação seriam repassados ao erário público. Assim, concedia-se uma nova emissão em notas do Tesouro Nacional, que circulariam durante um ano na Corte e província do Rio de Janeiro, resgatados mediante nova emissão de apólices (ACD, 11 jun. 1866, p. 66).

\section{OS ARGUMENTOS SOBRE AS PROPOSTAS PARA}

\section{ENFRENTAR A CRISE COMERCIAL EM 1866}

É impossível ignorar a importância da guerra do Paraguai nos meios políticos, em parte porque os rumos do conflito pressionaram oradores e seus aliados para que assumissem nos discursos posições cada vez mais comprometidas. A queda, em 1868, do gabinete presidido por Zacarias de Góis e Vasconcelos, um dos líderes do Partido Progressista e Chefe do Gabinete, que perdeu apoio quando apelou para a libertação de escravos para o serviço no Exército em meio à guerra, é um exemplo disso (Costa, 1996, p. 248).

Assim, à primeira vista, a guerra pareceu cobrar um custo político quase tão alto quanto o financeiro, motivo pelo qual vale a pena considerar como os políticos se aproveitaram dela naquela quadra. Na discussão dos projetos reformistas é significativo notar a quantidade de políticos que utilizaram o conflito de uma forma ou de outra. Entre os articulistas mais famosos estavam: João da Silva Carrão, advogado e jornalista liberal; Joaquim Octávio Nébias, magistrado liberal representante da província de São Paulo; Leandro de Chaves Melo Ratisbona, advogado liberal representante da província do Ceará; Francisco de Paula Santos, negociante liberal representante da província de Minas Gerais; Antônio Francisco de Paula Souza, médico liberal representante da província de São Paulo; Martinho Álvares da Silva Campos, médico liberal representante da província de Minas Gerais; José Bonifácio de Andrada e Silva, o moço, professor de direito liberal representante da província de São Paulo; e João José de Oliveira Junqueira Júnior, magistrado conservador representante da província da Bahia.

Muitos deles com bom trânsito no governo, mesmo que de diversos matizes políticos, não ficaram indiferentes à situação de crise sistêmica, havendo até mesmo certa convergência de interesses no tocante ao financiamento das 
tropas brasileiras. Como em qualquer debate político, pode-se supor que a benevolência dos parlamentares em relação ao assunto pode ter sido oportunista, e da mesma forma pode estar relacionada apenas com a busca da vitória de um projeto. Entretanto, pelo acompanhamento dos discursos parece legítimo levantar a hipótese de que nesse momento os políticos expressaram uma preocupação genuína contra um inimigo comum. Pelo que se pôde encontrar nos debates parlamentares, muitos estavam comprometidos com o esforço de guerra, mas isso não se confundia necessariamente com o apoio ao gabinete. Isso explica por que Aureliano Cândido Tavares Bastos e Cristiano Benedito Otoni, ambos liberais, propuseram que o governo desvinculasse a medida de política econômica das propostas de financiamento dos gastos de guerra, pois se os custos do conflito eram urgentes, as modificações na política econômica podiam esperar por um momento de maior estabilidade para só então serem apreciadas.

Claramente os projetos assumiam caminhos diferentes para combater os problemas da praça comercial do Rio de Janeiro. Enquanto o projeto do ministro da Fazenda, João da Silva Carrão, combatia novas emissões e buscava reduzir a circulação geral, o do ministro da Agricultura, Paula Souza, concedia simultaneamente duas emissões para solucionar os reflexos de uma crise exógena. Na apreciação das medidas apresentadas, Martinho Álvares da Silva Campos, político liberal e representante da província de Minas Gerais, foi o primeiro a se manifestar contra a proposta do ministro da Agricultura, criticando o fato de Paula Souza não ter apresentado seu projeto a uma comissão alegando caráter emergencial. Exigiu que o ministro declarasse francamente se essa medida partia do gabinete ou era obra sua, porque parecia que os apuros da praça do Rio de Janeiro figuravam apenas como um pretexto e, na realidade, o texto continha uma medida financeira do ministério para socorrer o Tesouro e não a praça (ACD, 12 jun. 1866, p. 90).

Martinho Silva Campos argumentava que o aumento de emissão resultaria incontestavelmente em uma depreciação contínua do valor das notas emitidas pelo Banco do Brasil. O projeto favorecia, portanto, o ministério da Fazenda, não a praça do comércio, por isso desafiou os parlamentares a desmembrar o projeto em busca das alegadas medidas de auxílio aos comerciantes. Para ele, o argumento fundamental era que o fim da conversibilidade das notas bancárias esvaziava o motivo para que a emissão de papel-moeda não fosse realizada pelo governo. Quanto à carimbagem das novas emissões, que buscava reduzir-lhes o giro e facilitar o resgate, alegou ser isso um mito. O mesmo se afirmou em 1850, e no final elas acabaram correndo todo o Império, 
pois a necessidade lhes dava a circulação que a lei não previra ( $A C D, 12$ jun. 1866, p. 91).

João José de Oliveira Junqueira Júnior, representante da província da Bahia, juntou-se prontamente ao combate da proposta de Paula Souza, ressaltando que a oposição e o país ficariam mais tranquilos para debelar a crise na praça do Rio de Janeiro, enfrentar a Guerra do Paraguai e os reflexos da crise na Europa se os ministros não se sucedessem na apresentação de medidas contraditórias (ACD, 12 jun. 1866, p. 93). O parlamentar entendia que a situação era grave, mas não compreendia que melhoria pudesse produzir uma emissão ilegal para socorrer o Tesouro. Defendeu o sistema de papel-moeda - com emissão governamental - apelando ao patriotismo do Ministério para que não inundasse o país com papel bancário inconversível. Assim, mesmo um antigo "papelista" podia opor-se a um projeto de emissão em virtude de sua preferência por bilhetes do governo e não por notas bancárias (ACD, 12 jun. 1866, p. 94).

Silva Carrão, ministro da Fazenda, respondeu aos parlamentares lembrando que não se encontravam em uma situação cotidiana. O governo interveio, tratando de impedir um efeito em cascata sobre toda a economia, e por isso autorizou o Banco do Brasil a transpor o limite de sua emissão para salvar a praça. $\mathrm{O}$ ministro negava o abandono de qualquer de suas antigas posições sobre bancos. Para ele, essas instituições eram casas comerciais livres, submissas apenas ao Poder Judiciário; entretanto, o Banco do Brasil estava também sob a ação do governo, pois esse estabelecimento recebera como privilégio o curso forçado de suas notas. Destacava que o vencimento dos títulos em carteira era a maneira usual pela qual os bancos conseguiam contrair as emissões, mas, especialmente naquela conjuntura, lançava dúvidas sobre esse procedimento. Segundo ele, "quando é a verdadeira regra em que um banco de emissão não deve aceitar reforma de seus devedores? Quanto a mim, declaro que não sei. Nós, no nosso país, nunca poderemos ter bancos de circulação. É um erro que tomamos de um livro inglês ou francês, e imediatamente o queiramos transplantar para nós (apoiados); [...] Qual o país que tem uma agricultura de renda tão demorada como é a do Brasil?” (ACD, 12 jun. 1866, p. 96).

Todavia, talvez o mais contundente discurso da oposição tenha sido o de José Bonifácio de Andrada e Silva, o moço, representante da província de São Paulo (Abreu, 2004, p. 363). Segundo ele, a gravidade da questão era tamanha que até aliados do governo haviam pedido a realização de um inquérito para descobrir os reais motivos da crise. Rebateu o argumento de que a oposição estaria servindo-se da crise para tirar proveito político e respondeu: "não falo ao menos como oposicionista; advogo os interesses gerais do meu país, e 
procuro servi-lo sem dar fé de aplausos ou da censura; vou com a minha consciência (apoiados), não tenho que importar-me com a vontade dos governos; hei de emitir a minha opinião, tendo em vista o mandato que recebi" (ACD, 12 jun. 1866, p. 96).

Ele criticava o contraste entre a apatia do governo em um momento que exigia ação e a precipitação na adoção de uma medida que deveria ser discutida e ponderada (Sáez, 2015, p. 124).

Para o deputado, a crise tinha elementos conhecidos, alguns da crise de 1864 e não somente relacionados às notícias vindas da Europa. A causa principal era a larga emissão dos bilhetes do Tesouro e, assim, o pretenso socorro, em um cenário de excesso de meio circulante, era um abuso do governo ao forçar as emissões bancárias (ACD, 12 jun. 1866, p. 99). Bonifácio tratava isso como a união espúria da prepotência com o apadrinhamento daqueles que se beneficiariam imediatamente com a medida, e recolocava uma questão fundamental: quem devia emitir o papel-moeda? Os bancos particulares ou o governo? Segundo ele, a medida proposta de emissão particular só dividia as responsabilidades, aumentava a despesa e diminuía as garantias (ACD, 12 jun. 1866, p. 99).

Joaquim Octávio Nébias assumiu a tribuna e lembrou que o conselheiro José Dias de Carvalho, ex-ministro da Fazenda e pertencente à diretoria do banco, afirmara que o banco não teria excedido o limite de emissão. Admitindo-se a quebra do limite, no entanto, criticava a medida proposta porque só servia para legalizar o excedente, não para auxiliar qualquer ramo da economia (ACD, 12 jun. 1866, p. 100). Como os problemas eram conjunturais, a medida não daria solução às reclamações de todas as classes sociais e, o que era pior, o segundo projeto tratava da emissão de novos bilhetes do Tesouro que nunca seriam resgatados. Para ele, o que o governo queria era um crédito ilimitado transformando o Banco do Brasil em mera caixa de descontos para as necessidades da guerra. Terminada essa rodada de debates, o projeto de Paula Souza foi aprovado e passou para nova rodada de discussões (ACD, 13 jun. 1866, p. 102).

Em sua defesa, Paula Souza alegou que os parlamentares não estavam considerando a intenção original. Não se buscava uma solução definitiva para o setor bancário e comercial; ao contrário, era uma medida paliativa e emergencial. Segundo o ministro os projetos só eram diferentes à primeira vista, mas na essência lutavam para fortalecer o governo. Além disso, criticou a gestão do Banco do Brasil: 
Um banco privilegiado de depósito e emissão, que na gestão dos interesses confiados à sua administração não foi bastante feliz na escolha dos títulos que deviam formar o fundo de suas operações, de tal arte que esse banco, exclusivamente comercial, converteu-se para logo insensivelmente em banco hipotecário, tornando a maior parte dos seus capitais estagnados pelo seu emprego em efeito, embora seguros, cuja realização morosa não podia prestar-lhe os serviços precisos para suas evoluções comerciais, não podia dar-lhe de pronto os recursos que a rapidez dos movimentos mercantis exigia de um estabelecimento desta ordem. (ACD, 13 jun. 1866, p. 110, grifos meus)

Essas informações expunham os limites que a legislação profilática imposta ao setor bancário por Ângelo Moniz tinham em uma sociedade como a brasileira, em meados do século XIX. Nela, prestígio, rede de contatos e a confiança eram diretamente transferidos para o campo dos negócios e acabavam por se chocar com a modernização da vida financeira que transformava práticas e instrumentos de negócio antes tão personalistas (Andrade, 2015, p. 20). Tratando de atrair clientes, os bancos de depósito e o banco de emissão (Gambi, 2010, p. 16), ${ }^{1}$ ou seja, o Banco do Brasil, parecem ter passado a financiar crescentemente atividades não comerciais. Aparentemente, na opinião de algumas autoridades da época, isso não lhes conviria, pois se tratava de um tipo de investimento com retorno demorado, resultando na queda da oferta de crédito para o comércio. A declaração do ministro reforça a ideia de que o trabalho dos comissários de café e mesmo das casas bancárias fazia o crédito de fato chegar à lavoura, e, a julgar pelos valores comprometidos, isso não era uma novidade no setor (ACD, 13 jun. 1866, p. 111). Esse fato foi corroborado pelo estudo de Renato Leite Marcondes sobre a existência de bancos ofertando esse crédito desde a década de 1850, pelo menos - prática que tendeu a crescer no decorrer do século XIX (Marcondes, 2017, p. 15).

O setor bancário brasileiro vinha imobilizando seus capitais em proporções crescentes, em modalidades de empréstimo eventualmente mais demoradas do que a comercial. Nesse cenário, a proliferação de casas bancárias como instituições creditícias vai disputar espaço com o crédito de particulares como negociantes, comerciantes e capitalistas, estreitando os laços entres esses agentes e o sistema financeiro (Oliveira, 2016, p. 10). Como saída, o mercado buscava as notas do Banco do Brasil por terem curso forçado e serem resguardadas pelo governo. Entretanto, esse banco não estava imune nem às oscilações internacionais, nem aos efeitos de sua ligação com as hipotecas. Segundo declarações do ministro Paula Souza, as empresas deveriam sofrer as 
consequências de sua má administração, sentindo os efeitos das leis que regulavam o comércio, mas percebia-se que o próprio governo ficaria prejudicado caso optasse por contrair bruscamente as emissões. Além disso, notava-se que apesar das discordâncias sobre o instrumento de permuta a ser usado - notas do Tesouro ou do banco -, havia certa concordância entre os parlamentares sobre o socorro à praça (ACD, 13 jun. 1866, p. 111).

Pelo que se pode depreender dos debates, o medo reinante entre os opositores era que na proposta não havia qualquer definição de "necessidade". Os deputados Tito Franco de Almeida, Martinho Álvares da Silva Campos, José Fernandes Moreira e Joaquim Otávio Nébias ressaltavam que na redação da proposta não constava que todo bilhete do Tesouro corresponderia obrigatoriamente a depósitos efetivos; apenas criava a obrigação de o Banco do Brasil trocar notas do Tesouro em circulação por seus bilhetes.

A partir de então, a discussão se polarizou travada por Paula Souza e Silva Carrão defendendo a proposta, enquanto Martinho Álvares Campos, Tito Franco de Almeida, advogado liberal e representante do Pará, José Bonifácio, o moço, e Leandro Ratisbona atacando-a.

Para os opositores a situação exigia união do governo e não propostas emergenciais cujo efeito colateral seria o aprofundamento da crise. Destacavam que o próprio ministro da Fazenda, Carrão, tanto em seu relatório quanto no projeto apresentado à Câmara dos Deputados, reconhecia que a situação abalava a todos e resultava da emissão superabundante. Os parlamentares denunciavam que apesar de Paula Souza dizer-se aberto às emendas, desqualificava qualquer crítica e sustentava o projeto original. Franco de Almeida aludiu a votações em que ele e Carrão defenderam as mesmas posições, e afirmou que concordavam sobre a impotência do modelo do sistema bancário inglês em momentos de crise. O deputado também destacava que, apesar dos desmandos, existiam interesses legítimos e legais em jogo:

mesmo essas casas, cujo estado (à vista da declaração do honrado ministro da agricultura) eu julgo podres, que essas casas podres, que não serão salvas nem com 40 ou 50.000:000\$, estão entrelaçadas com o comércio lícito e com os interesses mais legítimos, e que este comércio lícito, e que essas casas sãs serão prejudicadas pelas podres, que a má gerência dos maus arrastará a boa gerência dos bons! (Apoiados da oposição). (ACD, 14 jun. 1866, p. 122)

Parecia-lhe que o que o governo queria era uma fábrica de dinheiro sob pretexto de auxiliar a praça. Para Almeida, se a intenção do governo era 
sincera, deveria autorizar o Tesouro a pagar ao Banco do Brasil e aos comerciantes o resgate das notas do Tesouro ainda em circulação (ACD, 14 jun. 1866, p. 123-124).

Francisco de Paula Santos, da província de Minas Gerais, se autodeclarava um prático por ter como profissão o comércio e dizia-se animado pelo consenso na ajuda à praça, pois notou que a divergência estava no modo como se daria esse auxílio ${ }^{2}$ (Andrade, 2015, p. 2-3). Defendeu o projeto discordando dos que apontavam a repetição dos erros cometidos na crise de 1864, quando o principal erro do governo tinha sido demorar em dar o auxílio. Também divergia do argumento da oposição de que os 8 mil contos de réis não seriam suficientes para combater os problemas, porque esse argumento desconsiderava o efeito tranquilizador que a intervenção surtiria na praça comercial, além de defender que o Banco do Brasil tinha melhores condições de resgatar bilhetes emitidos emergencialmente. Afirmava que o ministro da Agricultura não apresentara a medida como uma questão de gabinete, consentindo, portanto, na alteração do texto pelos parlamentares. Além disso, era contra a emissão pelo Tesouro porque ela acabaria entesourada pelos capitalistas ao invés de circular pela praça comercial e auxiliar a todos, como fora exposto pela Comissão da Praça do Comércio do Rio de Janeiro.

Martinho Campos louvou o pronunciamento de Santos porque estava legitimado por sua atividade e, baseado em seu conhecimento prático, concordou em que era preciso dar ajuda à praça comercial e, portanto, necessário instrumentalizar o governo para combater a crise; entretanto, discordava dos meios.

Segundo Bonifácio, o projeto apenas legalizaria a violação do limite e garantiria à praça comercial uma quantia mínima de auxílio. Por isso, acusava o projeto de não passar de uma medida enganosa e inútil. Para ele, as causas da crise eram falta de capital e superabundância de papel inconversível. Amparado em pressupostos da economia, o deputado tratava de demonstrar que as notas do Banco do Brasil, autorizadas pelo Poder Legislativo e com curso forçado, eram, na realidade, papel-moeda. Como parte de sua estratégia, o deputado buscou explorar ao máximo a inversão de posições políticas dos ministros que antes apoiavam a restrição de emissões e agora se colocavam a favor da ampliação.

Aqui, mais uma vez, o jogo político e a capacidade de articulação ganhavam relevo, demonstrando que os políticos deveriam ser habilidosos em justificar suas posições. Para Bonifácio, o desfecho era previsível: o Banco do Brasil ficaria afundado pelo aumento de suas emissões e, ao final, o governo 
teria de incorporá-lo para o salvar da bancarrota quando, na realidade, o próprio governo contribuíra para essa situação.

Terminada a rodada de discussões, houve o adiamento dos debates, só retomados em 18 de junho, quando o próprio ministro da Agricultura, Antônio Francisco de Paula Souza, realizou novo pedido de adiamento baseado no argumento de que novas notícias, vindas da Europa, chegaram em um paquete a vapor (ACD, 18 jun. 1866, p. 117). Aprovado o requerimento de adiamento, não consta nenhuma discussão sobre essa matéria em junho e, ao que parece, ela desapareceu do índice dos Anais da Câmara dos Deputados. Após essa data, a referência mais próxima sobre a questão monetária e bancária é a emissão do parecer das Comissões Reunidas do Orçamento e da Fazenda, em 3 de julho de 1866, formadas por Francisco de Paula Santos, negociante mineiro, Ambrósio Leitão da Cunha - o barão de Mamoré -, bacharel em direito, liberal representante da província do Pará; Manoel Pinto de Souza Dantas, magistrado, conservador moderado, representante da província da Bahia; Francisco Carlos Brandão, bacharel em ciências sociais e jurídicas, liberal representante da província de Pernambuco; João José Barbosa de Oliveira, médico, liberal representante da província da Bahia; João Silveira de Souza, professor de direito, liberal representante da província de Santa Catarina, com o voto discordante de Aureliano Cândido Tavares Bastos, doutor em direito, liberal representante da província das Alagoas (ACD, 9 abr. 1866, p. 75).

As Comissões reunidas emitiram um parecer concordando, em parte, com a proposta de Silva Carrão indicando que duas opiniões dividiam a atenção do país. A primeira era a de que se deveria cassar o direito de emissão concedido ao Banco do Brasil, de modo que esse banco se mantivesse apenas como banco de depósitos e descontos. A emissão, já efetuada, permaneceria em circulação, com o curso forçado, dando-se andamento à sua retirada gradual, tendo em vista que boa parte estava aplicada na lavoura. A segunda opinião acreditava que o Banco do Brasil deveria ser mantido, reformando-o e concedendo-lhe novas garantias e favores em contrapartida à defesa do interesse da indústria comercial e fabril, opinião que era apoiada pelas Comissões. Para elas, a situação em que se encontrava o Banco do Brasil era resultado de imprevistos como a falta de experiência, práticas de longo prazo nos investimentos e excesso de confiança na produção do café, o que era justificável na medida em que essa atividade apresentava resultados iguais ou melhores do que as indústrias comerciais (ACD, 3 jul. 1866, p. 18-19).

$\mathrm{Na}$ essência, o parecer favorecia o banco e resguardava os interesses dos acionistas, até mesmo aumentando o limite dos dividendos distribuídos entre 
os acionistas, que passou de $7 \%$, no projeto, para $9 \%$, no parecer, contando ainda com a possibilidade do aumento no limite das emissões bancárias desde que fossem lastreadas em ouro. Os artigos aditivos tendiam a reorientar a atividade do banco para o setor comercial, o que revelava indícios de que, a despeito da restrição oficial, na prática, a tradição favorecera um afrouxamento da interdição de financiamento direto para a lavoura.

O voto discordante de Aureliano Cândido Tavares Bastos alegava que esse momento era o pior para se decidirem as questões do Banco do Brasil e do meio circulante. A Guerra do Paraguai pressionava o governo e, ao socorrer-se da emissão de papel-moeda, contra a qual diversas vezes o seu próprio ministro da Fazenda se manifestara, faria a questão bancária entrar em uma fase cada vez mais problemática. Provavelmente, seria preciso reformar a legislação bancária e analisar se ainda seria possível a retomada da conversão das notas em ouro, afinal, a possibilidade da emissão de papel-moeda em larga escala sob o pretexto dos gastos de guerra implicaria a revogação da legislação vigente.

Tavares Bastos propunha uma medida de empréstimo compulsório da reserva metálica do Banco do Brasil ao Tesouro, tendo em vista que as notas do banco circulavam com curso forçado e o montante depositado referia-se apenas a uma quarta parte da emissão total. Em troca do empréstimo gratuito do fundo disponível e de qualquer quantia necessária por conta da situação que o país enfrentava, o banco receberia o favor da manutenção da circulação de suas notas com curso forçado por todo o Império (ACD, 3 jul. 1866, p. 22). $\mathrm{Na}$ realidade, nenhuma dessas posições era novidade: reformar o banco, optar por um tipo específico de emissão, sanear o sistema financeiro etc., todas eram discussões que vinham se desenrolando havia muito tempo. Conforme Thiago Gambi assinalou, "Forçados pela impossibilidade de retorno à conversibilidade metálica, os saquaremas, representados pelas posições de Itaboraí, migraram da defesa da divisão do banco em duas repartições, uma de descontos e outra de emissão, para a reformulação total de seu banco, transformando-o num banco hipotecário" (Gambi, 2010, p. 436-437).

\section{O PROJETO SENATORIAL DE 1866}

A proposta senatorial foi apresentada em julho de 1866 por José Inácio Silveira da Motta, professor de direito e representante da província de Goiás, e previa que o governo ficasse autorizado a modificar o acordo celebrado com o Banco do Brasil. O banco cessaria, portanto, de emitir notas à vista e ao portador, mas poderia realizar outras operações como empréstimos hipotecários 
ou receber depósitos. Para esse fim seria o banco dividido em duas repartições distintas e independentes. A repartição hipotecária receberia, como fundo exclusivamente destinado a operações, a soma de 35.000:000\$ em títulos da carteira do banco. Tratava-se de quantias que fossem as mais próprias para serem convertidas em títulos hipotecários. Essa legislação contava que cessando o estado de guerra, a Assembleia Geral assinalaria na lei do orçamento de cada exercício a quantia que deveria ser aplicada ao resgate do papel-moeda.

No mesmo dia em que foi apresentada no Senado, a proposta foi remetida à Comissão da Fazenda do Senado composta pelo então visconde de Itaboraí, bacharel em matemática e senador pelo Rio de Janeiro; Carlos Carneiro de Campos, professor de direito e senador por São Paulo; e visconde de Souza Franco, magistrado e senador pelo Pará. O resultado do trabalho das Comissões do Senado foi apresentado dias depois. Em 27 de julho de 1866, o grupo de trabalho posicionou-se a favor da essência da proposta de Motta, apesar de propor algumas alterações no texto aceitas por ele, segundo o próprio parecer (ACD, 27 jul. 1866, p. 194-196). Exatamente um mês depois, em agosto, o texto apresentado pela comissão foi aprovado e enviado para a Câmara dos Deputados para dar prosseguimento aos trâmites.

O curto tempo de discussão, tendo em vista que em muitos dias não houve sessão por falta de quórum, demonstra que o apoio à reforma era grande. A maioria dos pronunciamentos buscava explicar que a situação do banco não permitia a continuação de seu funcionamento como banco de emissão. Durante esse período, o maior opositor do projeto foi o visconde de Jequitinhonha, advogado baiano e senador pela Bahia, que se colocava cabalmente contrário ao que chamou de peste da moeda-papel. Sua posição conflitava com a do visconde de Itaboraí, a de Souza Franco e a de Zacarias de Góis, todos declaradamente favoráveis à proposta das Comissões.

Aprovada em 4 de setembro de 1866, tem origem a seção hipotecária do Banco do Brasil. A novidade foi que nenhum dos dois célebres antagonistas dos períodos anteriores, Itaboraí e Franco, admitia erro em suas opiniões; ao contrário, acreditavam que o Banco do Brasil havia sido mal gerenciado e, por isso, a situação exigia uma saída de compromisso como esta.

\section{CONSIDERAÇÕES FINAIS}

Os anais do Parlamento se mostraram fontes ricas para acompanhar a mentalidade da elite política na segunda metade do século XIX, que é o fundamento deste trabalho. Neles é possível identificar conceitos econômicos, 
autores mencionados, modelos políticos e econômicos. Contudo, o mais interessante é notar a veemência com que alguns dos representantes públicos se envolviam nas propostas apresentadas.

Longe de apenas referendar as propostas que o Poder Executivo enviava para o Legislativo, o Parlamento foi a arena de discussão de assuntos delicados como crescimento econômico, organização do sistema bancário e direito de emissão. Não raro foi encontrar políticos cobrando outros políticos sobre os resultados trazidos pela adoção de determinado projeto, o que exigia astúcia política, habilidade e capacidade de rearticulação para rebater eventuais críticas, mas, talvez o mais intrigante seja notar que, muitas vezes, os políticos pertenciam ao mesmo partido. Situações como essa servem para se questionar se as práticas políticas imperiais eram tão orquestradas e monolíticas quanto a divisão estrutural entre conservadores e liberais o supõe.

O suplício de Tântalo simbolizou o desespero e a frustração em relação à dúvida que por vezes pairava nos debates: como metalizar uma economia que não se metalizava? Na realidade, como se pôde notar, essa é uma redução de uma série de processos mais complexos, pois, além das questões estritamente econômicas, há uma prática política efervescente que buscava responder às diversas situações pelas quais o Brasil passou. Se no flanco externo existiram a Guerra do Paraguai, a quebra do banco inglês Overend \& Gurney e a guerra Austro-Prussiana, no flanco interno uma série de processos cobravam a atenção do governo - como o aumento de oferta do crédito hipotecário, a manutenção do valor da moeda, os custos da guerra e a modernização da economia brasileira (Schulz, 1996).

Com esse quadro geral, percebem-se os desafios que a política imperial enfrentou com o surgimento de novas posições políticas, novos partidos e novos interesses. Ao mesmo tempo, nota-se a dificuldade que os políticos vivenciaram naquilo que pareceu ser um teste à sua habilidade no jogo político, a saber, em que momento empenhar sua reputação na aprovação de determinada medida.

Em relação aos estudos sobre a prática política, ainda são poucos os trabalhos que tomam os debates parlamentares como fundamentais nas decisões estabelecidas pelo governo. São ainda em menor número os que buscam fazer um esforço para acompanhar a historicidade em relação às práticas e conceitos político-partidários de modo a perceber esses instantes decisivos - como, por exemplo, a alteração da política econômica na década de 1860 - como um momento crítico para os políticos frente às pressões da opinião pública. Interessante notar que estudos recentes como o de Leandro Braga de Andrade 
(2015) avançaram na compreensão da trajetória política dos representantes públicos entre a localidade, a região e a nação, pois esses nexos iluminam a formação e reformulação das redes de apoio com as quais os políticos eram obrigados a dialogar e às quais deviam prestar contas.

No campo econômico parecem faltar estudos como os de Thiago Gambi (2010) que busquem contextualizar os pressupostos econômicos de modo a compreender que era necessário ter apoio político para a aprovação dos planos. Da mesma forma, quando se tomam apenas as decisões em relação às políticas econômicas do período, perdem-se as variações propostas e os caminhos alternativos e, portanto, o leque das opções que podem ganhar apoio e se mostrar vitoriosas com o tempo. Apesar do crescente número de estudos sobre a segunda metade do século XIX, especialmente no campo econômico, resta um problema com relação à historicidade dos conceitos e mesmo à forma como eles foram enunciados naquele momento.

\section{FONTES}

Anais da Câmara dos Deputados (ACD). (Diversos anos). Disponíveis em: http://imagem.camara.gov.br/diarios.asp?selCodColecaoCsv=A.

Atas do Conselho de Estado Pleno (ACEP). Terceiro Conselho de Estado Pleno - $3^{\circ}$ CE, 7 nov. 1850 a 20 fev. 1857. Disponíveis em: https://www.senado.leg.br/publicacoes/anais/pdf/ACE/ATAS4-Terceiro_Conselho_de_Estado_1850-1857.pdf.

\section{REFERÊNCIAS}

ABREU, Eide Sandra de A. de. O evangelho do comércio universal: o desempenho de Tavares Bastos na Liga Progressista e no Partido Liberal (1861-1872). 2004. Tese (Doutorado em História) - Universidade Estadual de Campinas (Unicamp). Campinas, 2004.

ANDRADE, Ana Maria R. de. 1864: conflito entre metalistas e pluralistas. 1987. Dissertação (Mestrado em História) - Universidade Federal do Rio de Janeiro (UFRJ). Rio de Janeiro, 1987.

ANDRADE, Leandro Braga de. Um representante da "classe dos homens práticos": negócios e política na trajetória do comendador Francisco de Paula Santos durante o Império. In.: CONGRESSO BRASILEIRO DE HISTÓRIA ECONÔMICA, 11.; CONFERÊNCIA INTERNACIONAL DE HISTÓRIA DAS EMPRESAS, 12., Vitória, ES, 2015. (Mimeogr.). 
COSTA, Wilma Peres. A espada de Dâmocles: o exército, a guerra do Paraguai e a crise do Império. São Paulo: Hucitec; Campinas: Ed. Unicamp, 1996.

GAMBI, Thiago F. Rosado. O banco da Ordem: política e finanças no império brasileiro (1853-66). 2010. Tese (Doutorado em História) - FFLCH, Universidade de São Paulo (USP). São Paulo, 2010.

HOMERO. A Odisseia. São Paulo: Cultrix, 2006.

IRWIN, Neil. Os grandes alquimistas financeiros: as histórias secretas dos presidentes dos três principais bancos centrais do mundo em uma economia em chamas. Rio de Janeiro: Elservier, 2014.

MARCONDES, Renato Leite. Hipotecas, mudanças institucionais e o Banco do Brasil na segunda metade do século XIX. In: CONGRESSO BRASILEIRO DE HISTÓRIA ECONÔMICA, 12.; CONFERÊNCIA INTERNACIONAL DE HISTÓRIA DE EMPRESAS, 13., Niterói, 2017. (Mimeogr.).

OLIVEIRA, Thiago Alvarenga de. Os pequenos credores na bancarrota das casas bancárias cariocas em 1864. In: CONFERÊNCIA INTERNACIONAL DE HISTÓRIA ECONÔMICA, 6.; ENCONTRO DE PÓS-GRADUAÇÃO EM HISTÓRIA ECONÔMICA, 8., São Paulo, 2016. (Mimeogr.).

SÁEZ, Hernán Enrique L. Nas asas de Dédalo: um estudo sobre o meio circulante no Brasil entre os anos de 1840 a 1853. São Paulo: Humanitas, 2010.

SÁEZ, Hernán Enrique L. O tonel das danaides: um estudo sobre o debate do meio circulante no Brasil entre os anos de 1850 a 1866 nas principais instâncias decisórias. 2015. Tese (Doutorado em História Econômica) - Universidade de São Paulo (USP). São Paulo, 2015.

SCHULZ, John. A crise financeira da abolição: 1875-1901. São Paulo: Edusp: Instituto Fernand Braudel, 1996.

\section{NOTAS}

${ }^{1}$ Bancos de emissão: aqueles que tinham permissão para emitir notas ou bilhetes mediante autorização legal.

${ }^{2}$ Francisco de Paula Santos era negociante de grandes quantias, e entre seus negócios contavam-se: comércio de escravos, negócios com mineradoras estrangeiras, importação e exportação de gêneros, empréstimos a juros e especulação com títulos da dívida pública. 